\title{
Traditional, phytochemical, and biological aspects of Rosa alba L.: a systematic review
}

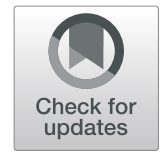

\author{
Anju Verma ${ }^{1 *} \mathbb{D}$, Rajni Srivastava ${ }^{1}$ (D), Pankaj Kumar Sonar ${ }^{2}$ (D) and Ramprakash Yadav $^{3}$ (D)
}

\begin{abstract}
Background: Rosa alba L. belongs to the family Rosaceae. This species is widely cultivated in Europe, Asia, North America, and Northwest Africa due to its fragrance, ornamental, and medicinal values. It is commonly known as white oil-bearing rose, white rose, white rose of York, backyard rose, and sufaid gulab.

Main text: Rosa alba L. has many biological properties like antioxidant, antimicrobial, antifungal, antifertility, teratogenic, memory enhancing, cytotoxic, and genotoxic activities. The essential oil of Rosa alba L. possesses good antimicrobial activity and consists of many chemical constituents like- citronellol, geraniol, nerol, linalool, citral, carvacrol, eugenol, etc.

Conclusion: This article briefly reviews the cultivation, traditional uses, phytochemistry, and biological activities of Rosa alba L. Many research papers have been published on the proposed plant and still, there is a very vast scope of research on it. Therefore, this review will be very fruitful for those scientists who are doing or plan to do research work on this plant. All the scientific findings written in this review are explored from Google web, Google Scholar, PubMed, ScienceDirect, Medicinal and Aromatic Plants Abstracts (MAPA), and SciFinder. To date, it is the first systematic review article of such kind, on this plant.
\end{abstract}

Keywords: Rosaceae, Rosa alba L., White rose of York, Backyard rose, Sufaid gulab, Citronellol, Geraniol

\section{Background}

Rosa alba L. is a perennial flower shrub of the genus Rosa and family Rosaceae comprises 95 genera and 3000 species across the world. This species easily hybridize from different parts of the world which have given rise to the many cultivars of garden roses. Moreover, 435 taxa, 308 species, 13 subspecies, 28 varieties, 17 forms, and 71 natural hybrids have been recognized in Rosa. This is one of the largest and most important aromatic and medicinal genera of this family, vital in folk medicine, pharmacological, and commercial value due to its essential oils and volatile products. Most of its species are native to Asia, Europe, North America, and Northwest Africa. While Rosa alba L. is found in the central-

\footnotetext{
*Correspondence: rinki.anju1983@gmail.com; rinki_anju@yahoo.co.in 'Department of Pharmaceutical Sciences, Faculty of Health Sciences, Sam Higginbottom University of Agriculture, Technology and Sciences, Prayagraj, Uttar Pradesh 211007, India

Full list of author information is available at the end of the article
}

west region in the state of Goiás, Brazil and some areas of Turkey, popularly known as white rose or yard rose or backyard rose or white rose of York or Sufaid gulab [1-5]. Various groups of compounds like flavonoids, anthraquinones, saponins, tannins, monoterpenes, triterpenes, sesquiterpenes, aldehydes, phenolic/alcoholic compounds, and minerals are reported in this species [6-10]. Symptoms of little leaf disease, i.e., yellowing and shortening of internodes, were observed in the Rosa alba L. due to the association of Candidatus Phytoplasma asteris-related strain which is firstly reported by Chaturvedi et al. in 2009 [11].

\section{Main text \\ Plant description and taxonomy [1] \\ Kingdom:Plantae \\ Division:Magnoliophyta \\ Class:Magnoliopsida \\ Order:Rosales}

\section{Springer Open}

(- The Author(s). 2020 Open Access This article is licensed under a Creative Commons Attribution 4.0 International License, which permits use, sharing, adaptation, distribution and reproduction in any medium or format, as long as you give appropriate credit to the original author(s) and the source, provide a link to the Creative Commons licence, and indicate if changes were made. The images or other third party material in this article are included in the article's Creative Commons licence, unless indicated otherwise in a credit line to the material. If material is not included in the article's Creative Commons licence and your intended use is not permitted by statutory regulation or exceeds the permitted use, you will need to obtain permission directly from the copyright holder. To view a copy of this licence, visit http://creativecommons.org/licenses/by/4.0/. 
Family:Rosaceae

Genus:Rosa

Species:Rosa alba L.

Rosa alba L. or rosebush is a little-large tree or shrubs up to $1.8 \mathrm{~m}$ in height with perfect velvety white roses of pleasant smell, therefore attracting insect pollination. Its branches are wide apart, big, bent downwards, and have thorns. It can grow in cold and unsuitable soils. The leaves are simple, palminer shaped with reserved trichomes, reticulated ribs, and small side lances. The central rib is elevated and fishbone. Flowers are usually in the form of large clusters as a rosette with 3 or more flowers that bloom throughout the year. Then, 5-70 but generally 15-40 in numbers of pure white-colored petals form the corolla in an overlapping manner. Stigma is not apparent; therefore, the carpel is not developed. The androecium has short stamens with poorly formed anthers. Sepals are round and mostly seesaw teethed [1, 12]. University of Arid Agriculture, Rawalpindi, Pakistan (UAAR) reported the pollen morphology of the flower as the length of pollen $20 \mu$, breadth $10 \mu$, size $20 \times 10 \mu$, and shape of pollen is elliptical. UAAR has also reported the $95 \%$ fertility of pollen [13].

\section{Cultivation}

The first white rose was cultivated by Greeks and Romans [1]. In the last century, Rosa alba L. had been cultivated in small areas of Europe, primarily the Rose Valley of Bulgaria [14, 15]. Plantings are located in the areas on the Ridge of Sredna Gora Mountain and presently in the region of sub-Balkan valleys. Due to the low quantity of essential oil in white roses, the lands used for its farming decreased noticeably throughout the last century [16]. Essential oil content in the petal has increased by $13 \%$ to $33 \%$ after the application of pulsed electric fields (PEF) with an energy input of $10 \mathrm{~kJ} / \mathrm{kg}$ on fresh rose blossoms. The PEF effect on the petals was examined by scanning electron microscopy (SEM) and found the increment of yield. The chemical composition on the treatment of $10 \mathrm{~kJ} / \mathrm{kg}$ was optimal in regards to the quality of the product [17]. The maximum oil content in the white rose of Bulgaria was found to be at 12 o'clock $(0.216 \%)$ and the potential to synthesize a high percentage of terpene alcohols up to $43.97 \%$ [18].

\section{Traditional use}

Generally, the leaves, root, flowers, and fruits are useful parts of Rosa alba L. The leaves are considered as rubefacient, lactagogue, and also have insecticidal properties. The leaf juice is used as external application for the treatment of piles. A decoction of leaves and roots is useful in the treatment of diarrhea. Yellow oil of the root is reported for strong anthelmintic action [19]. Rosa alba L. is cultivated mainly for the production of aromatic water while fruits are used in the production of food preparations and sold commercially. In Tunisia, aromatic water is made from Rosa $x$ alba (Nesri) called Nesri water, which is commonly used as a flavoring agent in the preparation of jam, marmalade, cake, and drinks. Hydrodistillate product of the flowers is used to prevent cardiovascular diseases [9]. The hydrosol obtained from the flowers is used as an antioxidant supplement for the treatment of oxidative stress etiology [20]. All fragrance products obtained from the plant are used in aromatherapy, phytotherapy, perfumery, and cosmetics. Rosa alba L. is traditionally used as tea for the treatment of eye troubles, vaginal candidiasis, and laxative [1]. Rose oil is also used in the preparation of various skin creams/ointment as fragrance or perfuming agent [21].

\section{Quality control studies \\ Swelling index}

The swelling index is defined as the volume in milliliter which is produced up by the swelling of $1 \mathrm{~g}$ of plant material on the particular sets of conditions. It gives an idea about the mucilage content of the drug; therefore, it is useful in the evaluation of those crude drugs which contain mucilage [22]. The swelling (intumescent) index of the petal and leaf powder has been determined and their average values are reported in Table 1 . Results revealed that the presence of significant amount of mucilage in the leaf. In the pharmaceutical industry, the plant mucilages are used as excipients like thickeners, binding agents, emulsion stabilizers, disintegrating agents, suspending agents, gelling agents, and film formers for the preparation of various dosage forms. Therapeutically, it is utilized as antidiabetic, antioxidant, anticancer, angiotensin-converting enzyme (ACE) inhibitor, wound healing agent, etc. [23].

\section{Moisture and ash contents}

Moisture and total ash contents of the petals and leaves of the Rosa alba L. is reported by Fabio da Silva et al., which is represented in Table 1.

\section{Microscopic analysis}

Microscopic details of the leaf and stem of Rosa alba L. have been reported by Fabio da Silva Santos et al. (2014). Palisade and lacunous parenchyma are observed in the cross-section of leaves. Palisade parenchyma was observed with two layers of cells occupying about onethird of the mesophyll while lacunous parenchyma occupying about two-thirds of the mesophyll. Both epidermises of the leaf are uniseriate with unicellular trichomes (hairs) and stomata. Thus the leaf is amphistomatic type. Druses (crystals) were found in the crosssection of the stem and observed intense brighten in 
Table 1 Swelling index, moisture and total ash contents of the powder of petals and leaves of Rosa alba $\mathrm{L}$

\begin{tabular}{|c|c|c|c|c|c|c|}
\hline \multirow{2}{*}{$\frac{\text { Sample }}{\text { Rosa alba L. }}$} & \multicolumn{2}{|c|}{ Ash content (\%) } & \multicolumn{2}{|c|}{ Moisture content (\%) } & \multicolumn{2}{|c|}{ Swelling index } \\
\hline & Petal & Leaf & Petal & Leaf & Petal & Leaf \\
\hline & 5.22 & 9.23 & 4.45 & 4.71 & 4.4 & 11.7 \\
\hline
\end{tabular}

polarized light. According to Ferri et al. (2003), druse is the set of incomplete crystallized crystals around a common nucleus [24].

\section{Phytochemical profile}

Qualitative tests of the leaves and petals of Rosa alba L. have been performed for the detection of secondary metabolites [1]. Results of the tests showed positive test for flavonoid in the leaves and petals that are indicating the presence of a considerable amount of these compounds in this species while tests of phenolic compounds and anthraquinone showed positive in leaves only. According to Simões et al. (2007), phenolic compounds are generally constituents of volatile oils. It is believed that when preparing the alcoholic extract of the petals, their phenolic elements are destroyed that is why the result of phenolic compounds in the test comes negative. Saponins were also absent in both leaves and petals while tannins have been found in the petals only [6].

\section{Chemical constituents and other characteristics}

Various chemical constituents reported in the leaves, flowers, and fruits of Rosa alba L. are structurally represented in the Fig. 1. Out of them, the essential oil was found as chief constituent. The major components of the essential oil are geraniol, heneicosane, nonadecane, citronellol, linalool, $\beta$ phenylethyl alcohol, nerol, neral, geranial, eugenol, methyleugenol, nonadecene, eicosane, and tricosane [7]. Mileva et al. also reported the quantitative information of citronellol, $n$-nonadecane, $n$-heneicosane, geraniol, nerol, citral, and eugenol in the essential oil, with the help of gas chromatography (GC) [8]. The abundance of some components like $\alpha, \beta-$ unsaturated aldehydes, and alcohols such as eugenol and linalool are reported in the leaves and 2-phenylethanol in flowers with well-documented biological properties. It is reported that the volatile oil obtained from leaves, applicable in the food industry, while oil obtained from flowers seems more appropriate in the cosmetic and perfume industries. The leaves, flowers, and fruits of the plant are rich sources of essential minerals. Therefore, leaves and flowers can be consumed as a salad and/or decoction, while fruits can be eaten fresh as a dessert or processed to jam. In another study, tannins, ellagitannins, and flavonoids were reported in petals while mucilage and anthraquinones in the leaves [10]. The quantitative analysis of the volatile oils from leaf, flower, and fruits of Rosa $x$ alba is represented in the Fig. 2 [9]. Georgieva et al. (2019) performed gas chromatographymass spectrometric (GC-MS) analysis of hydrosol, which was produced by water-steam distillations of rose blossoms. They reported various monoterpene hydrocarbons, aliphatic hydrocarbons, oxygenated aliphatic hydrocarbons, oxygenated monoterpenes, oxygenated sesquiterpenes, triterpenes, and benzenoid compounds in that hydrosol. Out of them, trans-Geraniol and $\beta$ Citronellol were found $36.44 \%$ and $28.69 \%$ respectively. All the explored compounds and their quantities are represented in the Fig. 3. Geraniol, nerol, citronellol, and citral are the constituents of the essential oil, responsible for the antioxidants and antimicrobial effects. Pure geraniol and citronellol are better antimicrobial agents than rose hydrosol. In the plant, biogenesis of geraniol and citronellol occurs through the mevalonic acid pathway $[20,25]$. Significant changes in the content and composition of essential oil of Rosa alba L. were observed when it was investigated at various stages of its flowers development. Flowers from the population of white rose were investigated in six phases. The optimum quantity and quality of the essential oil was not found same at one time, but there was a correlation between the two indicators. The maximum content of essential oil was observed in the phase IV at the time of semi-opened petals. Authors have examined the content of flavonoids (such as quercetin) in the flowers at the different phases of its development. They found that the basic content of flavonoids is $11 \mathrm{mg} / \mathrm{g}$ and reported that with the opening of the flowers, the content of flavonoids is increases and reaches up to the maximum amount $(18 \mathrm{mg} / \mathrm{g})$ when flowers are fully open [26].

\section{Biological activities \\ Antioxidant activity}

A comparative antioxidant effect of hydrosols, prepared from the flowers of Rosa alba L. and Rosa demesana Mill., was evaluated and showed good capacity to inhibit $\mathrm{Fe}^{2+} /$ ascorbic acid-induced lipid peroxidation in the egg liposomal model system. The antioxidant effect of hydrosol of Rosa alba L. was found higher than those of Rosa damascena Mill. at all tested concentrations. On the basis of above findings, it is concluded that Rosa alba L. could be used as supplementary material with antioxidants in oxidative stress condition [20]. Piotr 
<smiles>CC(C)=CCC/C(C)=C\C=O</smiles>

Citral<smiles>CC(C)=CCC/C(C)=C\CO</smiles>

Nerol

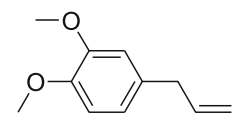

Methyleugenol

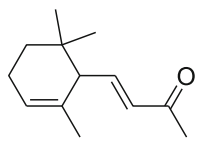

Ionone

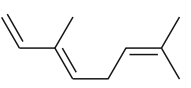

Ocimene<smiles>CC(C)=CCCC(C)CCO</smiles>

Citronellol<smiles>CC(C)=CCC/C(C)=C/CO</smiles>

Geraniol<smiles>C=CC(C)(O)CCC=C(C)C</smiles>

Linalool<smiles>CC(C)=CCC/C(C)=C\C=O</smiles>

Neral<smiles>CC(C)=CCC/C(C)=C/C=O</smiles>

Geranial<smiles>C=CCc1ccc(O)c(OC)c1</smiles>

Eugenol<smiles>C=CC(O)CCCCC</smiles><smiles>C=C1CCC2CC1C2(C)C</smiles>

Pinene<smiles>CCCCCCCCCCCC(=O)O</smiles>

Lauric acid<smiles>O=C(OCc1ccccc1)c1ccccc1</smiles>

Benzyl benzoate

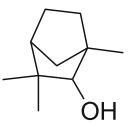<smiles>CCCCCCCCCO</smiles>

Fenchyl alcoho

Nonanol<smiles>CC(C)[C@@H]1CC[C@]2(C)[C@@H](O)CC[C@H](C)[C@H]2C1</smiles>

Eudesmol<smiles>CC(=O)OC/C=C(\C)CCC=C(C)C</smiles>

Farnesol
Geranyl acetate

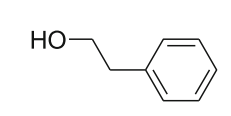

Phenylethyl alcohol<smiles>C=CC(C)(O)CCC1OC1(C)C</smiles>

cis-Linalool oxide<smiles>CC(C)=CCC/C(C)=C\CC/C(C)=C/CC/C=C(\C)CC/C=C(\C)CCC=C(C)C</smiles>

Squalene

Fig. 1 Chemical structures of some compounds reported in Rosa alba $\mathrm{L}$

Brzezinski and Lorenzo Martini (2019) have reported in their letter to the editor that the antiradical capacity of Rosa alba L. is $72 \mu \mathrm{g} / \mathrm{ml}$ at the concentrations of $100 \mu \mathrm{g} / \mathrm{ml}$. They have also written in their letter about the usefulness of rose in the treatment of severe rosacea (rosacea is a long-term skin condition that typically affects the face characterized by redness, pimples, swelling, small and superficial dilated blood vessels often the nose, cheeks, forehead, and chin). The principle of DPPH (2, 2-diphenyl-1-picrylhydrazyl) assay is based on hydrogen atom transfer reaction and substrate polarity. Therefore, the presence of hydroxyl group in the geraniol, nerol, and citronellol may be an option for the hydrogen donation and/or superoxide scavenging activity [7]. Rubero and Barata (1999) have demonstrated that the free radical scavenging activity is the cumulative effect of essential oil's ingredients (nerol, eugenol, geranol) due to their polar bonded hydrogen atoms [27].

\section{Antimicrobial activity}

Antimicrobial effect of essential oil obtained from Rosa alba L. was evaluated against Gram-positive bacterial strains, belonging to genera Staphylococcus and Bacillus; Gram-negative bacterial strains, belonging to genera Escherichia, Pseudomonas, Salmonella, and Citrobacter; and some yeasts, belonging to genera Candida. Results of the study revealed that the Gram-positive bacteria were found to be more sensitive than Gram-negative bacteria, especially Pseudomonas spp. were found to be more resistant to the essential oil and pure components. The pure citronellol, geraniol, and nerol have demonstrated higher antimicrobial activity than the isolated 


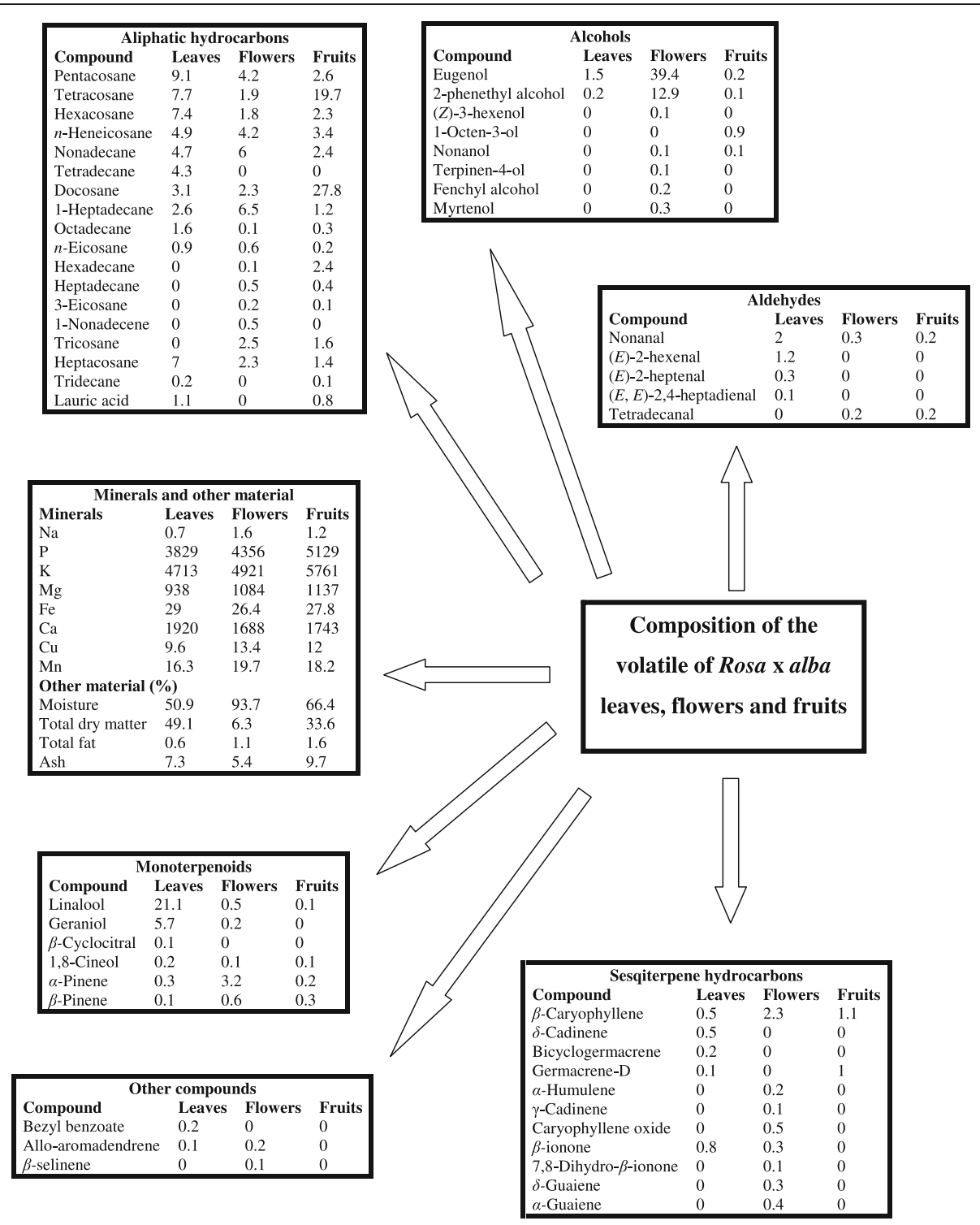

Fig. 2 Composition of the volatile oil (\% peak area) of Rosa $x$ alba leaves, flowers and fruits

one [7]. Rosa alba L. also showed significant antimicrobial effect against Staphylococcus aureus, Escherichia coli, and Candida albicans [28]. In another study, six essential oils of the Rosa genus and their ingredients were evaluated for their antifungal activity against Aspergillus flavus and Aspergillus niger. Findings of the study showed larger resistance of Aspergillus niger against rose oil in contrast to Aspergillus flavus. Antifungal activity of the essential oil is mainly due to the presence of its geraniol, nerol, and citronellol. Some more antimicrobial screening studies revealed that the rose oil found to be less effective against Gram-positive Enterococcus faecalis as compare to Streptococcus mutans and most effective against Gram-negative Aggregatibacter actinomycetemcomitans [8]. The lipophilic character of monoterpenes present in essential oils may be responsible for antimicrobial effect by disrupting the permeability of microbial cytoplasmic membrane for protons and bigger ions [16, 29,30].

\section{Antifertility and teratogenic activity}

Leaf powder of Rosa alba L. has mixed with an equal quantity of gum-acacia and double distilled water for preparing the dose of $175 \mathrm{mg} / \mathrm{kg}$. This dose was administered in albino rats orally once a day for 10 days in post-mating period for the evaluation of its antifertility effects. Results of the study depicted the fertility control levels up to $19 \%$. Marked malformations have been observed in newborns in cases where the pregnancy was not terminated [31]. 


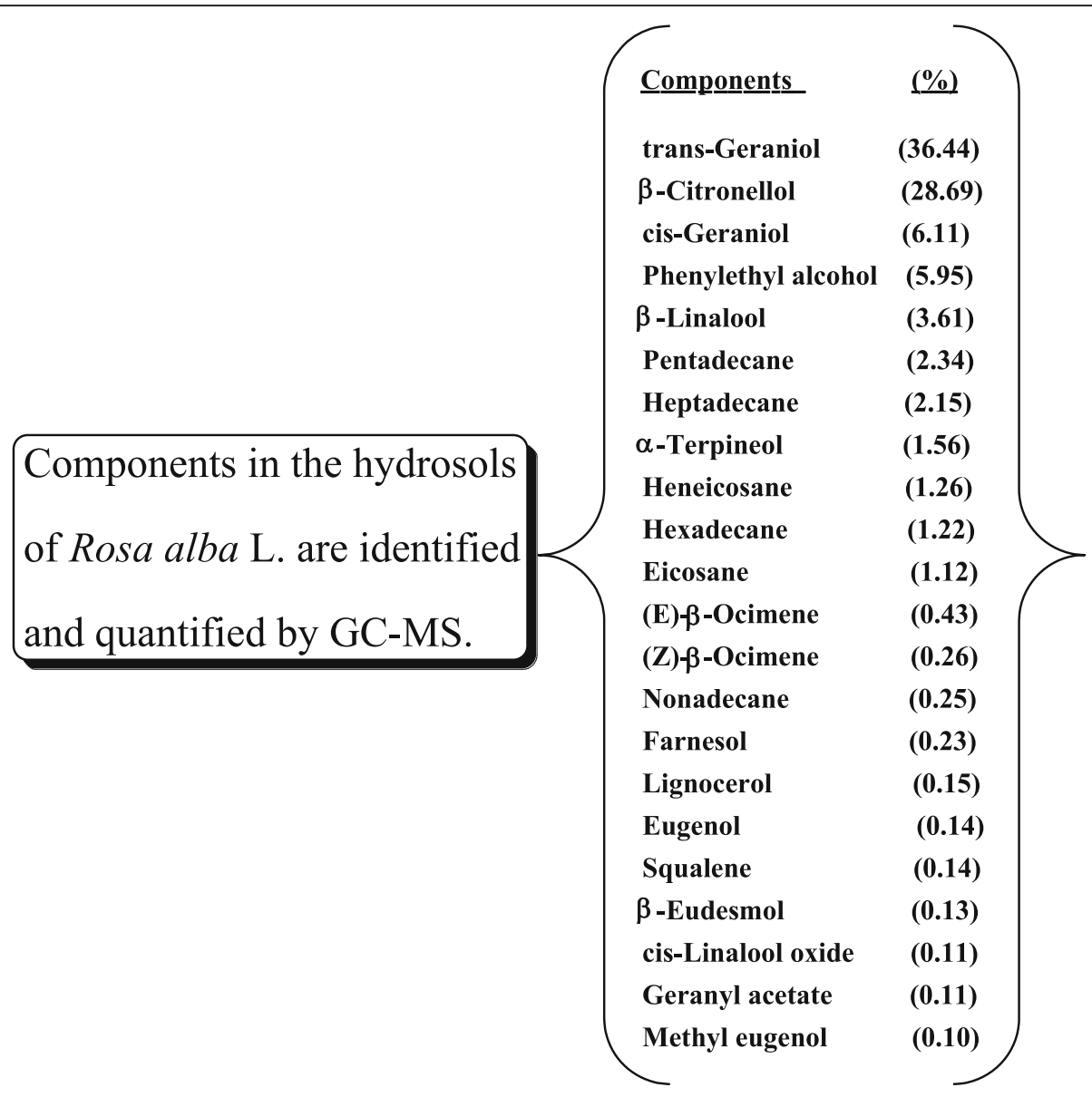

Fig. 3 GC-MS analysis of the hydrosols of Rosa alba L

\section{Cytotoxic and genotoxic activity}

Jovtchev et al. have evaluated the cytotoxic and genotoxic activity of Rosa alba L. through classical cytogenetic methods and comet assay. They used 1-methyl-3-nitro-1nitrosoguanidine as a standard mutagen. The essential oil was found to be inactive up to $1000 \mathrm{mg} / \mathrm{ml}$ on root tip meristem cells isolated from Hordeum vulgare [32]. Generally, essential oils and their components are safe in low concentrations while several researchers have reported that the higher dose $(500 \mathrm{mg} / \mathrm{ml})$ of geranial (citral A) and geraniol are responsible for cytotoxic and genotoxic effects in human cells [33, 34]. Geraniol inhibits prostate cancer growth by targeting cell cycle and apoptosis pathways [35].

\section{Memory-enhancing activity}

The memory-enhancing activity of the aqueous extract of Rosa alba L. was evaluated on three-month-old male Swiss albino mice. Elevated plus-maze and passiveavoidance apparatus served as the exteroceptive behavioral models and diazepam-induced amnesia served as the interoceptive behavioral model in the study. Mice were treated with 100, $200 \mathrm{mg} / \mathrm{kg}$ p.o. doses of Rosa alba L. and $200 \mathrm{mg} / \mathrm{kg}$ i.p. dose of piracetam as a standard nootropic agent. The results of the study showed that Rosa alba L. enhanced learning and memory in animals, as announced by transfer-latency and improved step-down latency. On the other hand, Rosa alba L. significantly reversed diazepam-induced amnesia. The plant has also improved memory power by inhibiting the enzyme cholinesterase. The nootropic activity of Rosa alba L. extracts may be due to the improvement of memory in the absence of cognitive deficits [36, 37].

\section{Stress-induced skin-barrier disruption}

Essential oil of Rosa alba L. has been evaluated against two major stress-induced effects like activation of the hypothalamo-pituitary-adrenocortical (HPA) axis and skin-barrier disruption in the rats and humans. It is stated that the inhalational treatment of rose oil significantly controlled the plasma corticosterone and the number of c-Fos-positive cells in the hypothalamic paraventricular nucleus. Rose oil also maintains the skinbarrier disruption in both rats and humans. It also increases the salivary concentration of cortisol in humans 
by controlling the elevation of transepidermal water loss [38]. Pharmacology underlying the suppressive effects of rose essential oil on the HPA axis and TEWL (transepidermal water loss) is not known but two possibilities are there. The first one is that the absorbed perfume component of rose essential oil via membrane of the nose or lungs triggers a certain reaction in the brain and/or skin, with consequent reductions of stress-induced HPA activation and skin-barrier disruption. The second possibility is that upon inhalation of oil, the olfactory nerves may be activated which directs to inhibition of the activities of stress-related forebrain regions, such as hypothalamic paraventricular nucleus (PVN) [39].

\section{Bradykinin and substance $P$ antagonist}

Breton et al. (2000 and 2003) obtained United States Patents for inventions of novel substance P and bradykinin antagonist compositions comprising at least one extract of at least one plant of the rosaceae family. Rosa alba L. was also one of the plants in their composition as substance $\mathrm{P}$ and bradykinin antagonists. These inventions also narrate to the administration of Rosa alba $\mathrm{L}$ extract as the active species or agent for treating disorders associated with an excessive synthesis and/or release of substance $\mathrm{P}$ and bradykinin [40, 41].

\section{Conclusion}

Rosa alba L. belongs to the family Rosaceae. Leaves, root, flowers, and fruits are useful parts of this ornamental plant with a variety of traditional values, as a tea for the treatment of eye troubles, vaginal candidiasis, and as laxative. It is used in the production of aromatic water, food preparations, as a flavoring agent for drinks, production of jam, marmalade, and cake. All fragrance products obtained from this plant are used in aromatherapy, phytotherapy, perfumery, and cosmetics. This holds a variety of biological activities like-antioxidant, antimicrobial, antifertility, teratogenic, cytotoxic, genotoxic, memoryenhancing, antistress, bradykinin, and substance P antagonist activities. Various chemical components are identified/isolated from different parts of the plant like essential oil, alcohols, aldehydes, monoterpene hydrocarbons, sesquiterpene, minerals, etc. This plant is not too much explored in pharmacological aspects yet the authors have made their full effort to compile the entire pharmacology published earlier on this plant. The plant contains a wide range of natural antioxidants like flavonoids, terpenoids, phenolic compounds, etc. which can neutralize the free radicals and thus prevent the development of many chronic diseases/disorders related with oxidative stress and reactive oxygen species (ROS) like neurodegenerative disorders, cancer, cardiovascular disease, diabetes, hepatic disorders, and diseases associated with aging. Though, phytochemical studies of the plant have been done enough. Herbal formulation and development part of the plant must also be explored in the future. Biological standardization of the isolated compounds and their synthesis in the laboratory should also be explored as potential drug candidates.

\section{Abbreviations \\ UAAR: University of Arid Agriculture, Rawalpindi, Pakistan; PEF: Pulsed electric fields; SEM: Scanning electron microscopy; GC: Gas chromatography; GC- MS: Gas chromatography-mass spectrometry; DPPH: 2, 2-Diphenyl-1-picrylhy- drazyl; HPA: Hypothalamo-pituitary-drenocortical; ROS: Reactive oxygen species; PVN: Paraventricular nucleus; MAPA: Medicinal and Aromatic Plants Abstracts; ACE: Angiotensin-converting enzyme; p.o.: Per oral; \\ i.p.: Intraperitoneal; TEWL: Transepidermal water loss}

\section{Acknowledgements}

This review paper is supported by Sam Higginbottom University of Agriculture, Technology and Sciences, Prayagraj, Uttar Pradesh, India.

\section{Authors' contributions}

All authors have studied and permitted the final manuscript for communication. AV created the idea, conducted the literature searches and wrote the manuscript. RS worked together with the correction and regulation of text and references. PKS equally contributed as $A V$, in the data analysis and organizing the manuscript in the proper format. RY collaborated with the correction, updating, and regulation of references. The authors read and approved the final manuscript.

Funding

Not applicable.

Availability of data and materials

All data and material are available upon request.

Ethics approval and consent to participate

Not applicable.

Consent for publication

Not applicable.

Competing interests

No competing interests to declare.

\section{Author details}

${ }^{1}$ Department of Pharmaceutical Sciences, Faculty of Health Sciences, Sam Higginbottom University of Agriculture, Technology and Sciences, Prayagraj, Uttar Pradesh 211007, India. ${ }^{2}$ Government Pharmacy College, B.R.D. Medical College Campus, Gorakhpur, Uttar Pradesh 273013, India. ${ }^{3}$ Central Animal House, B.R.D. Medical College, Gorakhpur, Uttar Pradesh 273013, India.

Received: 29 July 2020 Accepted: 21 October 2020

Published online: 11 November 2020

\section{References}

1. da Silva SF, Cardoso JR, Mendes JV, Pinto MV (2014) Pharmacognostic study of Rosa alba L. Revista Eletrônica FMB 7:136-150

2. Basim E, Basim H (2003) Antibacterial activity of Rosa damascena essential oil. Fitoterapia 74:394-396. https://doi.org/10.1016/s0367-326x(03)00044-3

3. Madhupriya BN, Dantuluri VSR, Manimekalai R, Rao GP, Khurana SP (2017) Association of different groups of phytoplasma in flower malformation, phyllody, foliar yellowing, and little leaf disease of rose (Rosa sp.). J Hortic Sci Biotech 92:424-431. https://doi.org/10.1080/14620316.2017.1286953

4. Agaoglu YS, Ergül A, Baydar N (2000) Molecular analysis of genetic diversity oil rose (Rosa damascena mill.) grown Isparta (Turkey) region. Biotechnol Biotechnol Equip 14:16-18. https://doi.org/10.1080/13102818.2000.10819080

5. Basu SK, Zandi P, Cetzal-Ix W, Sengupta R (1994) The genus Rosa: an aristocrat from the plant family with class, color and fragrance. IRSEN Newsletter of Iranian Society of Environmentalists Available via Google Scholar. https://www.irsen.org/newse.html. Accessed 16 July 2020 
6. SIMÕES CM, Schenkel EP, Gosmann G, Mello JC, Mentz LA, Petrovick PR (eds) (2007) Farmacognosia da planta ao medicamento. UFSC, Florianópolis

7. Mileva M, Kusovski VK, Krastev DS, Dobreva AM, Galabov AS (2014) Chemical composition, in vitro antiradical and antimicrobial activities of Bulgarian Rosa alba L. essential oil against some oral pathogens. Int J Curr Microbiol App Sci 3:11-20

8. Mileva M, Krumova E, Miteva-Staleva J, Kostadinova N, Dobreva A, Galabov AS (2014) Chemical compounds, in vitr o antioxidant and antifungal activities of some plant essentia I oils belonging to Rosaceae family. C R Acad Bulg Sci 67:1363-1368

9. Hosni K (2011) Rosax alba: source of essential minerals and volatile oils. Nat Prod Bioprospect 1:57-61. https://doi.org/10.1007/s13659-011-0012-x

10. Brzezinski P, Martini L (2019) Rosacea treated with rose petals: a calembour that affords intriguing results. Our Dermatol Online 10:393-395. https://doi. org/10.7241/ourd.20194.23

11. Chaturvedi Y, Singh M, Rao GP, Snehi SK, Raj SK (2009) First report of association of'Candidatus Phytoplasma asteris' (16Srl group) with little leaf disease of rose (Rosa alba L.) in India. Plant Pathol 58:788. https://doi.org/10. 1111/j.1365-3059.2009.02058.x

12. Agaoglu YS (2000) Rose oil industry and the production of oil rose (Rosa damascena mill.) in Turkey. Biotechnol Biotechnol Equip 14:8-15. https://doi. org/10.1080/13102818.2000.10819079

13. Noor MJ, Mushtaq A, Rehana A, Aulia K, Sadaf P (2004) Palynological studies of cultivated plant species at University of Arid Agriculture, Rawalpindi, Pakistan. Asian J Plant Sci 3:476-479. https://doi.org/10. 3923/ajps.2004.476.479

14. Kovatcheva N, Zheljazkov VD, Astatkie T (2011) Productivity, oil content, composition, and bioactivity of oil-bearing rose accessions. HortScience 46: 710-714. https://doi.org/10.21273/HORTSCl.46.5.710

15. Rusanov K, Kovacheva N, Rusanova M, Atanassov I (2013) Flower phenotype variation, essential oil variation and genetic diversity among Rosa alba $\mathrm{L}$. accessions used for rose oil production in Bulgaria. Sci Hortic 161:76-80. https://doi.org/10.1016/j.scienta.2013.07.010

16. Gochev V, Dobreva A, Girova T, Stoyanova A (2010) Antimicrobial activity of essential oil from Rosa alba L. Biotechnol Biotechnol Equip 24:512-515. https://doi.org/10.1080/13102818.2010.10817892

17. Dobreva A, Tintchev F, Heinz V, Schulz H, Toepfl S (2010) Effect of pulsed electric fields (PEF) on oil yield and quality during distillation of white oilbearing rose (Rosa alba L.). Zeitschrift für Arznei-\& Gewürzpflanzen 15:127-132

18. Dobreva A, Kovacheva N (2010) Daily dynamics of the essential oils of Rosa damascena mill. And Rosa alba L. Agric Sci Technol 2:71-74

19. Kumar A (2009) Rosa alba Linn. (rose the healer of heart ) has medicinal properties also In: Science 2.0. Available via blog. https://www.science20. com/humboldt_fellow_and_science/blog/rosa_alba_linn_rose_healer_ heart_has_medicinal_properties_also\#: :text=|to20is\%20used\%20as\%2 Oan,for\%20sores\%20on\%20domestic\%20stock. Accessed 26 Sep 2020

20. Georgieva A, Dobreva A, Tzvetanova E, Alexandrova A, Mileva M (2019) Comparative study of phytochemical profiles and antioxidant properties of hydrosols from Bulgarian Rosa alba L. and Rosa Damascena mill. J Essent Oil-Bear Plants 22:1362-1371. https://doi.org/10.1080/0972060X. 2019.1699867

21. Allen LV Jr (2010) Cooling ointment for dry skin. US Pharm 35:38-39

22. Pradhan N, Gavali J, Waghmare N (2015) WHO (World Health Organization) guidelines for standardization of herbal drugs. IAMJ 3:2238-2243

23. Ameri A, Heydarirad G, Mahdavi Jafari J, Ghobadi A, Rezaeizadeh $H_{\text {, }}$ Choopani R (2015) Medicinal plants contain mucilage used in traditional Persian medicine (TPM). Pharm Biol 3:615-623. https://doi.org/10.3109/ 13880209.2014.928330

24. Ferri MG, Menezes NL, Monteiro WR (2003) Glossário Ilustrado de Botânica. NBL Editora, Rio de Janeiro

25. Suga T, Shishibori T (1973) The biosynthesis of geraniol and citronellol in Pelargonium roseum Bourbon. Bull Chem Soc Jpn 46:3545-3548. https://doi. org/10.1246/bcsj.46.3545

26. Dobreva A, Gerdzhikova M (2013) The flavonoid content in the white oilbearing rose (Rosa alba L.). Agric Sci Technol 5:134-136

27. Ruberto G, Baratta TM (1999) Antioxidant activity of selected essential oil components in two lipid model systems. Food Chem 69:167-174. https:// doi.org/10.1016/S0308-8146(99)00247-2

28. Carvalho AH, Nunes NS, Resende DG, Reis YP (2008) Verificação de atividade antimicrobiana de Extratos de Plantas Silvestres. Revista Eletrônica de Biologia (REB) 1:2-7
29. Özkan G, Sagdiç O, Baydar NG, Baydar H (2004) Antioxidant and antibacterial activities of Rosa Damascena flower extracts. Food Sci Technol Int 10:277-281. https://doi.org/10.1177/1082013204045882

30. Cristani M, D'Arrigo M, Mandalari G, Castelli F, Sarpietro MG, Micieli D, Venuti V, Bisignano G, Saija A, Trombetta D (2007) Interaction of four monoterpenes contained in essential oils with model membranes: implications for their antibacterial activity. J Agric Food Chem 55:6300-6308. https://doi.org/10.1021/jf070094x

31. Sethi N, Nath D, Singh RK, Srivastava RK (1990) Antifertility and teratogenic activity of some indigenous medicinal plants in rats. Fitoterapia 61:64-67

32. Jovtchev G, Stankov A, Georgieva A, Dobreva A, Bakalova R, Aoki I, Mileva M (2018) Cytotoxic and genotoxic potential of Bulgarian Rosa alba L. essential oil-in vitro model study. Biotechnol Biotechnol Equip 32:513-519. https:// doi.org/10.1080/13102818.2017.1423245

33. Sinha S, Jothiramajayam M, Ghosh M, Mukherjee A (2014) Evaluation of toxicity of essential oils palmarosa, citronella, lemongrass and vetiver in human lymphocytes. Food Chem Toxicol 68:71-77. https://doi.org/10.1016/j. fct.2014.02.036

34. Queiroz RM, Takiya CM, Guimarães LP, Rocha GD, Alviano DS, Blank AF, Alviano CS, Gattass CR (2014) Apoptosis-inducing effects of Melissa officinalis L. essential oil in glioblastoma multiforme cells. Cancer Invest 32: 226-235. https://doi.org/10.3109/07357907.2014.905587.

35. Kim SH, Bae HC, Park EJ, Lee CR, Kim BJ, Lee S, Park HH, Kim SJ, So I, Kim TW, Jeon JH (2011) Geraniol inhibits prostate cancer growth by targeting cell cycle and apoptosis pathways. Biochem Biophys Res Commun 407:129134. https://doi.org/10.1016/j.bbrc.2011.02.124

36. Naikwade NS, Mule SN, Adnaik RS, Magdum CS (2009) Memory-enhancing activity of Rose alba in mice. IJGP 3:239-242. https://doi.org/10.4103/09738258.56283

37. Avneet G, Pal SM, Siddhraj SS (2018) A review on herbal Ayurvedic medicinal plants and its association with memory function. JPHYTO 7:162-166

38. Fukada M, Kano E, Miyoshi M, Komaki R, Watanabe T (2012) Effect of "rose essential oil" inhalation on stress-induced skin-barrier disruption in rats and humans. Chem Senses 37:347-356. https://doi.org/10.1093/chemse/bjr108

39. Fukada M, Kaidoh T, Ito A, Yano T, Hayashibara C, Watanabe T (2007) "Green odor" inhalation reduces the skin-barrier disruption induced by chronic restraint stress in rats: physiological and histological examinations. Chem Senses 32:633-639. https://doi.org/10.1093/chemse/bjm031

40. Breton L, Pineau N, LOreal SA (2000) Substance P antagonists comprising rosaceae plant extracts US Patent 6,146,636, 14 Nov 2000

41. Breton L, Pineau N, LOreal SA (2003) Bradykinin antagonists comprising rosaceae plant extracts US Patent 6,586,020, 1 Jul 2003

\section{Publisher's Note}

Springer Nature remains neutral with regard to jurisdictional claims in published maps and institutional affiliations.

\section{Submit your manuscript to a SpringerOpen ${ }^{\circ}$ journal and benefit from:}

- Convenient online submission

- Rigorous peer review

- Open access: articles freely available online

- High visibility within the field

- Retaining the copyright to your article

Submit your next manuscript at $\boldsymbol{\nabla}$ springeropen.com 